\title{
Physical Self-Efficacy of Post-Secondary Colleges Swimmers in Hong Kong 香港大専游泳運動員的身體自我效能
}

\author{
Siu Yin Cheung Judy Ng \\ Department of Physical Education, \\ Hong Kong Baptist University, HONG KONG \\ 張小燕哭葉潔雲 \\ 香港浸會大學體育學系
}

\begin{abstract}
The subjects of this study were 121 (male $=76$, female $=45$ ) post secondary colleges swimmers. They ranged in age from 17 to 28 years $(M=20.36, S D=1.59)$. The swimmers were divided into 3 groups according to the year of participation in swimming. The Physical self-efficacy scale (Ryckman, Robbins, Thomton \& Cantrell, 1982) was administered and 2x3 ANOVA was utilized to analyze the mean difference in raw scores of the three dependant variables: Perceived physical ability (PPA), Physical self-presentation confidence (PSPC) and Physical self-efficacy (PSE). Results show that the PSPC and PSE scores of experienced swimmers are significantly higher than beginners. However, the PPA, PSPC and PSE scores of both males and females are similar.
\end{abstract}

\section{摘要}

本研究邀請了一百二十一名香港大專游泳運動員(男 $=76$, 女 $=45$ ) 參加, 他們的年齡是由 17 至 28 歲 (平均年齡 $=20.36$ )。他 們分別回答 Rychman, Robbins, Thornton 和 Cantrell (1982) 的身體自我效能問卷。根據運動員的比賽經驗分成三組, 用 $2 \times 3$ ANOVA 分析身體自我效能的三個因變數:感覺身體能力 (Perceived Physical Ability, PPA), 身體表現信心(Physical Self-presentation Confidence, PSPC)和身體自我效能 (Physical Self-efficacy, PSE)。結果指出有經驗的運動員的身體表現信心 (PSPC)和身體自 我效能 (PSE) 的分數比初學者高, 而男和女的和身體自我效能則分數相近。

\section{Introduction}

Behavioral changes are mediated by a common cognitive mechanism, self-efficacy, which is defined as "the conviction that one can successfully execute the behavior required to produce the outcomes" (Bandura, 1977, p. 193). Miller (1983) stated that "self-efficacy refers to self-belief in personal ability to execute specific behavior that will produce a particular result" (p. 285). Self-efficacy is fundamental to competent performance. Higher level of efficacy enhances performance while lower level inhibits it. Successful performance, vicarious experience, verbal persuasion and emotion arousal are the four sources of efficacy (Cox , 1998). Swimming is the most popular outdoor sports among the 20 to 39 years old adults in Hong Kong (Wu et. al.1998) and little research has been conducted to investigate the physical self-efficacy level of swimmers. Therefore, the primary purpose of this study was to examine the level of physical self-efficacy of Hong Kong post secondary colleges swimmers.

\section{Method}

\section{Subjects}

The subjects of this study were 121 ( 76 males, 45 females) Hong Kong Post Secondary Colleges swimmers. Their age ranged from 17 to 28 years $(M=20.36, S D=1.59)$. The swimmers were divided into 3 groups according to their year of competition in swimming. Group 1 were those with $0-1$ year, Group 2 were those with 2-5 years and Group 3 were those with more than 6 years of competition.

\section{Testing instrument}

The Physical Self-Efficacy Scale (PSES) (Ryckman, Robbins, Thornton, \& Cantrell, 1982) was used in this study. The PSES was utilized to assess individual differences in perceived physical competence and individual feelings of confidence in displaying 
skills in the presence of others. The scale consists of 22 items and is divided into 2 subscales: a. 10-item Perceived Physical Ability (PPA) and b. 12-item Physical Self Presentation Confidence (PSPC). The total score is the Physical Self-efficacy (PSE) ranges from 22 to 132. The higher the scores on the PSE reflect a stronger sense of Physical Self-efficacy. Test-retest reliabilities of physical self-efficacy (PSE), perceived physical ability (PPA), and physical self-presentation confidence (PSPC) were $0.85,0.69$, and 0.80 respectively. Internal consistencies of the scale ranged from 0.75 to 0.85 (Ryckman et. al., 1982). In addition, McAuley and Grill (1983) had conducted the PSE to 52 female collegiate gymnasts and concluded that PSE appeared to be a reliable and valid measure of general physical selfefficacy. Gayton, Matthews and Burchstrad (1986) also supported the validity of the PSE in a competitive sport setting.

\section{Procedures}

The investigation was conducted in Hong Kong in September 1998. Letters to explain the purposes and procedures of the study were distributed to the coaches of the swimming teams. The swimmers were invited to participate in this study voluntarily. They took about 20 minutes to complete the questionnaires.

\section{Results}

Data from the questionnaires were analyzed by utilizing the Statistic Package of Social Science for Window Version 8.0. Descriptive Statistics and $2 \times 3$ ANOVA (gender $x$ years of experience) were computed.

Tables 1 and 2 showed the means and standard deviations for male and female swimmers according to their gender and years of experience.

Table 1.Means and SD for the Swimmers on the Physical Self-Efficacy Scores.

\begin{tabular}{lllllll}
\hline Variables & $\underline{\mathrm{N}}$ & Male & & $\underline{\mathrm{N}}$ & Female & \\
\hline & 76 & $\underline{\mathrm{M}}$ & $\underline{\mathrm{SD}}$ & 45 & $\underline{\mathrm{M}}$ & $\underline{\mathrm{SD}}$ \\
\hline PPA & & 36.18 & 6.09 & & 36.24 & 6.25 \\
PSPC & & 46.78 & 5.89 & & 48.71 & 5.42 \\
PSE & & 82.96 & 9.82 & & 84.96 & 9.51 \\
\hline
\end{tabular}

Table 2. Means and Standard Deviations for Swimmers on the Physical Self-Efficacy Scores According to their Experience.

\begin{tabular}{|c|c|c|c|c|c|c|c|c|c|}
\hline Variables & $\underline{N}$ & \multicolumn{2}{|c|}{$0-1$ year } & $\underline{\mathrm{N}}$ & \multicolumn{2}{|c|}{$2-5$ years } & $\underline{\mathrm{N}}$ & \multicolumn{2}{|c|}{6 or above years } \\
\hline Males & 37 & $\underline{M}$ & $\underline{\mathrm{SD}}$ & $\overline{21}$ & $\underline{\mathrm{M}}$ & $\underline{\mathrm{SD}}$ & 18 & $\underline{\mathrm{M}}$ & $\underline{S D}$ \\
\hline PPA & & 36.95 & 5.56 & & 33.52 & 5.53 & & 37.72 & 7.07 \\
\hline PSPC & & 45.32 & 4.50 & & 45.67 & 5.61 & & 51.06 & 6.80 \\
\hline PSE & & 82.27 & 8.33 & & 79.19 & 9.27 & & 88.78 & 11.09 \\
\hline Females & 27 & $\underline{M}$ & $\underline{\mathrm{SD}}$ & 7 & $\underline{\mathrm{M}}$ & $\underline{\mathrm{SD}}$ & 11 & $\underline{\mathrm{M}}$ & $\underline{S D}$ \\
\hline PPA & & 34.78 & 6.58 & & 38.71 & 6.24 & & 38.27 & 4.63 \\
\hline PSPC & & 47.67 & 5.27 & & 50.29 & 0.15 & & 50.27 & 6.28 \\
\hline PSE & & 82.44 & 9.84 & & 89.00 & 8.23 & & 88.55 & 7.93 \\
\hline Total & 64 & & & 28 & & & 29 & & \\
\hline PPA & & 36.03 & 6.05 & & 34.82 & 6.04 & & 37.93 & 6.17 \\
\hline PSPC & & 46.31 & 4.99 & & 46.82 & 5.59 & & 50.76 & 6.50 \\
\hline PSE & & 82.34 & 8.90 & & 81.64 & 9.87 & & 88.69 & 9.85 \\
\hline
\end{tabular}

The result of 2 X 3 ANOVA at Table 3 demonstrated that significant differences were found on mean PSPC and PSE for college swimmers in three experience groups.

Table 3.2 × 3 ANOVA Comparing Physical Self-Efficacy Scores for Male and Female Swimmers in Three Experience Groups.

\begin{tabular}{|c|c|c|c|c|c|}
\hline Source & $\underline{\mathrm{SS}}$ & $\underline{\mathrm{df}}$ & $\underline{\mathrm{MS}}$ & $\underline{F}$ & $\mathrm{p}$ \\
\hline \multicolumn{6}{|l|}{ PPA } \\
\hline Sex & 31.83 & 1 & 31.83 & 0.88 & 0.349 \\
\hline Experience Gp. & 89.23 & 2 & 44.64 & 1.24 & 0.293 \\
\hline Sex x Exp. Gp & 216.60 & 2 & 108.30 & 3.01 & 0.050 \\
\hline Error & 4143.02 & 115 & 36.03 & & \\
\hline Total & 163123.00 & 121 & & & \\
\hline \multicolumn{6}{|l|}{ PSPC } \\
\hline Sex & 95.20 & 1 & 95.20 & 3.23 & 0.075 \\
\hline Exp.Gp. & 330.94 & 2 & 165.47 & $5.61 *$ & 0.005 \\
\hline Sex x Exp. Gp & 90.72 & 2 & 45.36 & 1.54 & 0.219 \\
\hline Error & 3393.33 & 115 & 29.51 & & \\
\hline Total & 276965.00 & 121 & & & \\
\hline \multicolumn{6}{|l|}{ PSE } \\
\hline Sex & 237.13 & 1 & 237.13 & 2.77 & 0.009 \\
\hline Exp.Gp. & 755.68 & 2 & 377.84 & $4.41^{*}$ & 0.015 \\
\hline Sex x Exp. Gp & 405.98 & 2 & 202.99 & 2.37 & 0.098 \\
\hline Error & 9859.04 & 115 & 85.73 & & \\
\hline Total & 859062.00 & 121 & & & \\
\hline
\end{tabular}

Table 4 showed the result of the Turkeys' Test for the PSPC and PSE scores. The "6 or above" group was significantly higher than the " $0-1$ " group for the PSPC score, while the "6 or above "group was significantly higher than the" $0-1$ " and "2-5" group for the PSE score.

Table 4. Tukey's Test Result for PSPC and PSE.

\begin{tabular}{|c|c|c|c|c|}
\hline Source & Mean & $0-1$ & $2-5$ & 6 or above \\
\hline \multicolumn{5}{|l|}{ PSPC } \\
\hline $0-1$ & 46.3125 & --_---- & -.5089 & $-4.4461 *$ \\
\hline $2-5$ & 46.8214 & & --.---- & $-3.937 *$ \\
\hline 6 or above & 50.7586 & & & -..-...- \\
\hline \multicolumn{5}{|l|}{ PSE } \\
\hline $0-1$ & 82.3437 & -..-- & .7009 & $-6.3458 *$ \\
\hline $2-5$ & 81.6429 & & -------- & $-7.0468 *$ \\
\hline 6 or above & 88.6897 & & & ------- \\
\hline
\end{tabular}

* Significant beyond the .05 level 


\section{Discussions}

Gender

The present study shows that the PPA, PSPC and PSE scores for both male and female swimmers are not significantly different. Mandell (1995) found similar result for collegiate soccer players. Watkins, Garcia and Turek (1994) also supported this finding.

Some researches found contradictory results: male has higher self-efficacy scores than females (e.g. Godin, \& Shephard, 1985; Lirgg, 1991 and Weinberg, Gould, \& Jackson, 1979). Cann (1991) pointed out that females received less support and encouragement to participate in sport activities. Jones, Swain and Cale (1991) conducted the self-confidence questionnaire to 28 male and 28 female university athletes and found that males had higher self-confidence score. Moreover, Corbin (1984) found females often lacked confidence under certain conditions in physical activity settings. Grayden (1997) stated that the perceived physical competence for girls were lower than boys. He explained that the feeling of self-worth is not static, it will be influenced by many factors. Women generally displayed less confidence than men on the male-appropriate tasks, while no gender differences were found on the female-appropriate tasks. (Grayden , 1997) In addition, Lirgg (1991) had utilized meta analysis to examine gender-differences in self-confidence in physical activity and pointed out that female has less confidence than male when the task was male oriented. He also reported that as female children grew older, their self-confidence decreased.

In the present study, male and female swimmers have similar physical self efficacy score, Grayden (1997) classified swimming as neutral sport activity and this may explain the finding of the present study.

\section{Experience}

The PSPC and PSE scores of experienced swimmers are higher than less experienced swimmers in this study. George (1994) stated that college baseball players had high self-efficacy score than high school players. On the contrary, Koczajowski (1997) compared the physical self-efficacy scores for professional and amateur golfers and no significant differences were found.

Schmidt (1991) stated that practice and experience can develop motor program and automaticity, thus the capability for skill performance can be improved. George (1994) pointed out that successful athletes demonstrated greater self-confidence than less successful athletes. Therefore, increase in year of experience may increase self-confidence.

According to Bandura (1977), enactive experience is one of the sources of efficacy information and personal performance accomplishments increase with year of experience. It is therefore not surprising to find in this study that experienced swimmers have higher self-efficacy score. In particular, the "6 or above" group had significant higher physical self efficacy. This may reflect that those who choose and persevere in swimming competition are those with higher physical self efficacy scores.

\section{References}

Bandura, A. (1977). Self-efficacy: towards a unifying theory of behavioral change. Psychological Review, 84 (2), 191-215.

Cann, A. (1991). Gender expectations and sports participation. In Diamant, L. (Ed.), Psychology of sports, exercise and fitness: social and personal issues (pp. 187-209). New York: Hemisphere.

Corbin, C.B. (1984). Self-confidence of females in sport and physical activity. Clinics in Sports Medicine, 3 (4), 895-908.

Cox, R. H. (1998). Sport psychology: concepts and applications (4th ed.). Boston, MA: McGraw-Hill.

Gayton, W. F., Matthews, G. R., \& Burchestead, G. N. (1986). An investigation of the validity and predictive marathon performance. Perceptual and Motor Skills, 63 (2), 752-754.

George, T. R. (1994). Self-confidence and baseball performance: a casual examination of self-efficacy theory. Journal of Sport and Exercise Psychology, 16, 381-399.

Godin, G., \& Shepherd, R. J. (1985). Gender differences in perceived physical self-efficacy among older individuals. Perceptual and Motor Skills, 60 (2), 599-602.

Graydon, J. (1997). Self-confidence and self-esteem in physical education and sport. In Clarke, G. \& Humberstone, B. (Eds.), Researching women and sport (pp. 68-77). Houndmills, England: Macmillian.

Jones, G., Swain, A., \& Cale, A. (1991). Gender differences in precompetition temporal patterning and antecedents of anxiety and self-confidence. Journal of Sport and Exercise Psychology, 13, 1-15. 
Koczajowski, D. L. (1997). State and trait sport-confidence and physical self-efficacy of professional and amateur female golfers. [ CD-ROM ]. International Installation for Sport and Human Performance. Abstract from: Sport Discus: Item: 450268

Lirgg. C. D. (1991). Gender differences in self-confidence in physical activity: a meta-analysis of recent studies. Journal of Sport and Exercise Psychology, 8, 294-310.

Mandell, R. A. (1995). The influence of role status, self-efficacy and soccer performance. [ CD-ROM ]. International Installation for Sport and Human Performance. Abstract from: Sport Discus: Item: 377606

McAuley, E., \& grill, D. (1983). Reliability and validity of the physical self-efficacy scale in a competitive sport setting. Journal of Sport Psychology, 5 (4), 410-418.

Miller, M. (1993). Efficacy strength and performance in competitive swimmers of different skill levels. International Journal of Sport Psychology, 24, 284-296.

Ryckman, R. M., Robbins, M. A., Thornton, B., \& Cantrell, P. (1982). Development and validation of a physical selfefficacy scale. Journal of Personality and Social Psychology, 42, 891-900.
Schmidt, R. A. (Ed.). (1991). Motor learning \& performance: from principles to practice. Champagin, IL: Human Kinetics.

Theodorakis, Y. (1995). Effects of self-efficacy, satisfaction, and personal goals on swimming performance. The Sport Psychology, 9, 245-253.

Watkins, B., Garcia, A. W., \& Turek, E. (1994). The relation between self-efficacy and sport performance: evidence form a sample of youth baseball players. Journal of Applied Sport Psychology, 6, 21-31.

Weinberg, R., Gould, D., \& Jackson, A. (1979). Expectations and performance: an empirical test of Bandura's self-efficacy theory. Journal of Sport Psychology, 1, 320-331.

Wu, G. K. H., Yeung, J., Weng, R., Ng, A., Mok, W. Y., \& Lam, J. J. (1998). The sports participation rate and sports injury pattern in the 20 to 39-years-old-adult in Hong Kong: a pilot study. Hong Kong Journal of Sports Medicine and Sports Science, 7, 26-32. 